\title{
The nature of agroparks: synergy versus risk
}

\section{a. Problem Statement}

The concept of agropark, an important element in metropolitan agriculture, emerged as a sustainable solution to many environmental and socio-economic problems confronting the agrofood sector (De Wilt and Dobbelaar, 2005, Veldkamp, et al., 2008). The last decade has seen continuous efforts in developing various versions of agroparks, (Smeets, 2009). This promising concept has, however, had very few successes in terms of implementation. The main obstacles seem to be institutional factors such as social resistance and lack of participation of private firms (Laan, 2009). There is a strong need to investigate the economic underpinnings of agroparks.

As a planning concept, an agropark is one integrated unit. Realization and functioning of this unit require therefore orchestrated efforts of different players at different segments and levels. Unless all activities are undertaken by a unitary actor, agropark requires cooperation and coordination among different actors. Economic agents have typically diverse interests, preferences and constraints, which may or may not align with the mission of an agropark. Sustainable cooperation in agroparks needs institutionalized collaboration among different economic agents.

From an institutional perspective, economic agents cooperate under certain 'rules of games' that are defined by the institutional environment, which is embedded in social norms and values (Williamson, 2000). If the economic operations of an agropark concern multiple self-interested agents, a governance structure must exist which defines the 'play of the game'. Governance structure refers to the institutional arrangements consisting of the rules by which an exchange is carried out and administered. It is the supporting structure for carrying out transactions (Hendrikse, 2003). Based on various agropark designs, it is yet unclear which governance structure will be used for agroparks. In other words, a well-specified institutional design of agroparks is missing.

Economic analysis of projects and operations requires correct identification of costs and benefits, which depend on institutional arrangements (Belli, et al., 2001). Lack of well-specified 
institutional design makes it difficult, if not impossible, for stakeholders to assess their own benefits and risks associated with agroparks. Different governance structures can create different incentive structures and risk interdependencies for the stakeholders. Interdependencies among different economic agents, accompanied by many uncertainties, creates complexity for the economic analysis of agroparks. In particular, knowledge questions pertaining to risk analysis are: How do institutional factors influence the development of agroparks and how do they affect financial-economic risks.

\section{b. Objectives}

The purpose of this paper is to describe the analytical framework for the economic analysis of agroparks, of which risk analysis is an integral element, and describe the methodological approach to analyzing financial-economic risks of agroparks, which takes into account of various institutional factors.

\section{c. Procedures}

To establish a frame of reference for various institutional factors, we first perform a four-level analysis as presented in Slangen et al. (2008), i.e., 1) socially embeddedness (Level 1); 2) institutional environment (Level 2); 3) governance structure (Level 3); 4) incentive structure (Level 4). The analytical framework rests on the four-level analysis of agropark as an economic phenomenon to construct the typology of various agroparks and corresponding risks to key stakeholders. Following the analytical framework, Section 3 explains and illustrates the methodology with a case. A number of issues related to the analytical framework and the methodology are discussed in Section 4. Section 5 concludes.

\section{d. Results}

Based on the 4-level analysis, agropark concerns institutional factors on four-levels of social analysis, which adds to the institutional challenge of developing agroparks. As economic institution, agroparks have distinctive features compared to regular firms. The key features are presented in Table 1. 
Table 1. Agropark as an economic phenomenon viewed from 4 levels of social analysis

\begin{tabular}{|c|c|c|}
\hline Level of analysis & Regular Firms & Agropark \\
\hline Level 1: Social embeddedness & Mission: fitting & Mission: leading/changing \\
\hline $\begin{array}{l}\text { Level 2: Institutional } \\
\text { environment: } \\
\text { Ownership, property } \\
\text { rights, formal } \\
\text { institutions }\end{array}$ & $\begin{array}{l}\text { Well defined } \\
\text { ownership and } \\
\text { property rights; } \\
\text { Existing rules and } \\
\text { regulations; }\end{array}$ & $\begin{array}{l}\text { Joint/Incomplete/not well- } \\
\text { defined ownership; } \\
\text { Lack of existing rules and } \\
\text { regulations; }\end{array}$ \\
\hline $\begin{array}{l}\text { Level 3: Governance structure } \\
\text { and coordination } \\
\text { mechanism: } \\
\text { park management and } \\
\text { internal coordination }\end{array}$ & $\begin{array}{l}\text { Market-based } \\
\text { operation and } \\
\text { cooperation }\end{array}$ & $\begin{array}{l}\text { Hierarchic structure, } \\
\text { Vertical and horizontal } \\
\text { integration through trust, } \\
\text { agreements, contracts, } \\
\text { authorities }\end{array}$ \\
\hline $\begin{array}{c}\text { Level 4: Incentive structure and } \\
\text { resource allocation }\end{array}$ & $\begin{array}{l}\text { Independent } \\
\text { based on market } \\
\text { prices and quantities }\end{array}$ & $\begin{array}{l}\text { Interdependent } \\
\text { and coordinated, based both } \\
\text { on market prices, quantities, } \\
\text { and contracts }\end{array}$ \\
\hline
\end{tabular}

To illustrate the synergies and risks of agroparks, a conceptual model is built which contains the essential relationships of an agropark. These relationships are graphically shown in Figure 1. Using Figure 1 as a frame of reference, features described in Table 1 are illustrated. Synergy and risks are described both in qualitative and quantitative terms. Synergetic effects include economies of scale, economies of scope, and value creation through internalization of (positive) externalities. Risks include system risks caused by positive correlations of negative effects and failure of cooperation due to various institutional factors.

Based on the simplified agropark which captures the essential relationships, a fault-tree analysis is performed to identify determinants of the success of an agropark. Financial-economic risks associated with agroparks are quantified using Monte-Carlo Simulation, using farm data and macroeconomic data from the Netherlands. 
Figure 1. Conceptual model of an agropark

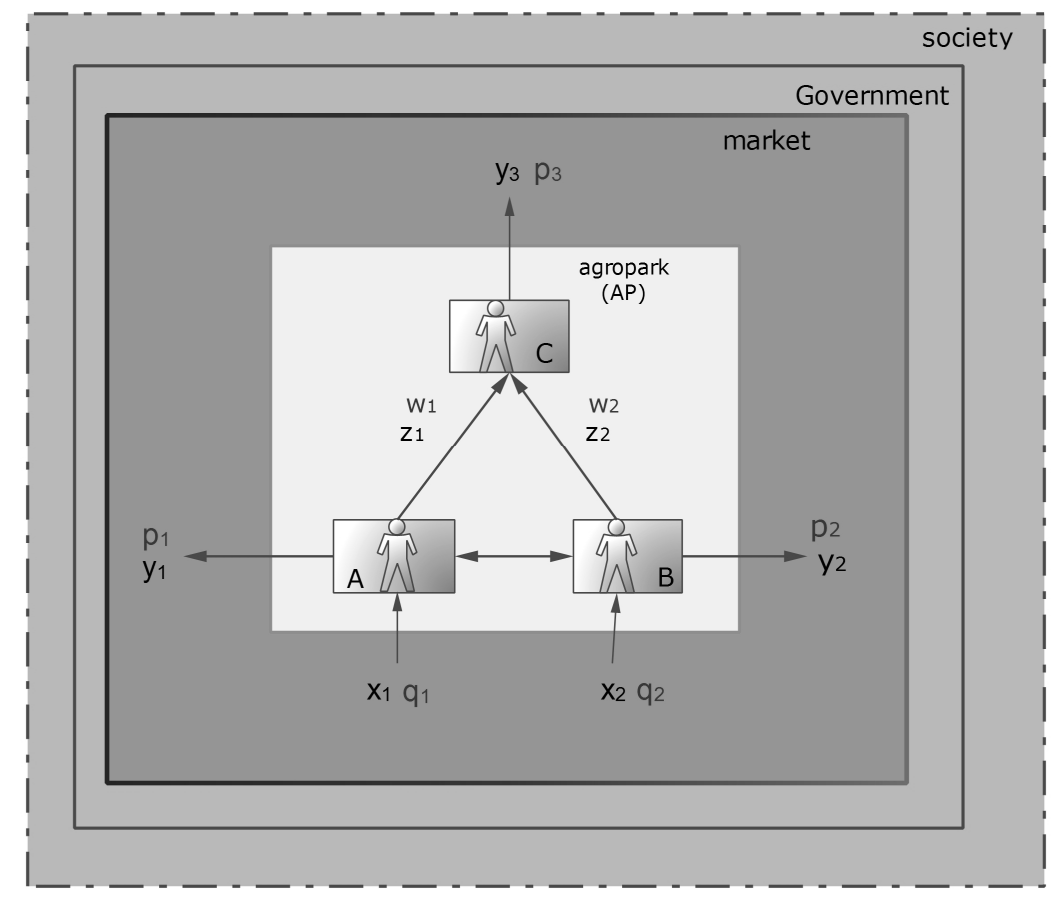

\section{e. Conclusions}

As institutionalized collaboration, agropark has economic potential. However, institutional factors constitute major risks to the planning and realization of agroparks. Economic planning is not a game against nature but a game against rational economic agents. Behavior of different stakeholders must therefore be taken into account when planning and organizing an agropark.

Quantitative risk analysis can help stakeholders in setting up the cooperation in an agropark. The methodology as described in this paper can be applied to agroparks in other countries. The results, however, are likely to be different as a result of different social-economic contexts.

\section{f. References}

Belli, P., et al. Economic analysis of investment operations: analytical tools and practical applications. WBI Development Studies. Washington, D.C.: The World Bank, 2001.

De Wilt, J. G., and T. Dobbelaar. "Agroparks: the concept, the responses, the practice." InnovationNetwork.

Demange, G., and M. Wooders (2005) Group Formation in Economics. Cambridge, Cambridge University Press.

Hendrikse, G. W. J. Economics and Management of Organizations: Co-ordination, Motivation and Strategy. London: The McGraw-Hill Companies, 2003. 
Khodabandehloo, Koorosh. "Analyses of robot systems using fault and event trees: case studies". Reliability Engineering and System Safety 53, (1996) 247-264.

Kydland, F. E., and E. C. Prescott. "Rules Rather than Discretion: The Inconsistency of Optimal Plans." The Journal of Political Economy 85, no. 3(1977): 473-492.

Laan, L. "Tackling institutional challenges in the development and realization of Agroparks." Wageningen University, 2009.

Olson, M. The Logic of Collective Action: Public Goods and the Theory of Groups. Vol. CXXIV. Harvard Economic Studies. Massachusetts: Harvard University Press, 1971.

Slangen, L. H. G., L. A. Loucks, and A. H. L. Slangen. Institutional economics and economic organisation theory. Wageningen, The Netherlands: Wageningen Academic Publishers, 2008.

Smeets, P. J. A. M. "Expeditie Agroparken: Ontwerpend onderzoek naar metropolitane landbouw en duurzame ontwikkeling." PhD Dissertation, Wageningen University, 2009.

Veldkamp, A., et al. "Triggering transitions towards sustainable development of the Dutch agricultural sector: TransForum's approach." Agronomy for Sustainable Development 28(2008): 1-10.

Vose, D., 2000. Risk Analysis: a Quantitative Guide. John Wiley \& Sons, Ltd Chichester.

Williamson, O. E. "The New Institutional Economics: Taking Stock, Looking Ahead." Journal of Economic Literature 38, no. 3(2000): 595-613.

Woolthuis, R. K., H. Bas, and N. Bart. "Trust, Contract and Relationship Development." Organization Studies 26, no. 6(2005). 